Article

\title{
Corporate Sustainability Performance: An Approach to Effective Sustainable Community Development or Not? A Case Study of the Luanshya Copper Mine in Zambia
}

\author{
Inonge Mutale ${ }^{1}$, Isabel B. Franco ${ }^{2,3, *(1)}$ and Masinja Jewette ${ }^{1, *}$ \\ 1 School of Mines, University of Zambia, Esat East Road Campus, Lusaka 32379, Zambia; \\ mutaleinonge@gmail.com \\ 2 Institute for the Advanced Study of Sustainability, United Nations University, 5 Chome-53-70 Jingumae, \\ Shibuya City, Tokyo 150-8925, Japan \\ 3 Australian Institute for Business and Economics (AIBE), The University of Queensland, St Lucia Campus, \\ Brisbane, QLD 4072, Australia \\ * Correspondence: connect@drisabelfranco.com (I.B.F.); jewette_masinja@yahoo.com (M.J.)
}

Received: 27 August 2019; Accepted: 16 September 2019; Published: 18 October 2019

\begin{abstract}
Corporate Sustainability Performance (CSP) is being promoted as a way in which corporations in the extractive industry can contribute to poverty eradication in developing resource regions. As such, the international debate on CSP has moved from whether companies ought to do it or not, to the extent to which it can contribute to sustainable development. Corporations worldwide have therefore reshaped their frameworks, rules, and business models to accommodate CSP. This article evaluates whether, through the implementation of CSP, companies are able to contribute to the sustainable development of host communities in developing countries. Against this backdrop, there exists a knowledge gap in Zambia as to what the actual contributions of CSP are towards sustainable community development. Through literature review and community data analysis, the results revealed that there was a mismatch in priorities between CSP and the expectations of community members. Findings show that CSP focused mostly on haphazard donations, an approach that has been proven to be unsustainable. Finally, CSP had little or negligible impact on most selected Sustainable Development Goals (SDGs). In view of these findings, the study suggests adopting sustainability frameworks that are tailored to the local context. Furthermore, formulation of CSP initiatives should take a triangular approach of communication that is inclusive of all stakeholders.
\end{abstract}

Keywords: corporate sustainability performance; mining industry; sustainable development; community; SDGs; Zambia

\section{Introduction}

In recent decades, the concept of Corporate Sustainability Performance (CSP) has gradually acquired greater importance in academic and professional fields [1]. However, there has been little empirical research conducted on the impact of CSP in developing resource regions [2-5]. The main concern is that CSP in developing resource regions not only fails to appreciate the uniqueness of each developing context but it is also devoid of the external pressure that exists in such regions and lacks partnerships with the government, the community, and the organization. It is therefore incorrect to just assume that CSP has the same effect on development in developed and in developing resource regions as insinuated by international development organizations [6,7].

In order to understand CSP and its impact on sustainable development, a case study of the China Nonferrous Metals Group Luanshya Copper Mine (hereafter referred to as CLM) was explored. 
Yin [8] defines a case study as any empirical enquiry that investigates a contemporary phenomenon within its real life context, more so when the boundaries between phenomenon and context are not clearly evident, and in which several sources of evidence are used. A case study aimed at establishing the exact impacts of CLM's CSP on development was chosen due to the fact that mining is being touted as a possible driver of development in resource rich countries [9]. Other than that, the ongoing criticism of the mining industry, by international trade unions, Non-Governmental Organisations, human rights organizations and environmental groups has caused mining companies to adopt CSP strategies to deflect the negative comments [10]. This study employed the use of both qualitative and quantitative methods in what is called the mixed method [11]. Using this method not only eliminates or neutralizes the biases inherent in any single method but also serves as a transformative purpose to change and advocate for marginalized groups, such as women, people with disabilities, and the poor [12]. This method was therefore considered as best suited in dealing with issues of marginalized people who are normally the intended beneficiaries of CSP initiatives in this case. Data were collected from primary and secondary sources, coded, and analyzed using SPSS and Python programming.

The study found that there was a mismatch between the priorities of CLM and that of the people of Mpatamatu who were the intended beneficiary of CSP. While the company invested more in health and the least in agriculture, the community expected more investment aimed towards agriculture in relation to agricultural support and skills training. The community indicated that health and infrastructure development were least preferred as compared to having employment and provision of education. The results reviewed that CSP focused mostly on haphazard donations and lacked a guiding framework. The mismatch in priorities also indicates that stakeholders such as the government, community members, and other interested parties are never involved in decision-making processes.

Although the value of corporate sustainability is widely accepted within scholarly literature, these initiatives thus far appear to have achieved very little impact in the achievement of sustainable community development aspirations. This investigation works to increase our knowledge regarding specific priority areas, which, when targeted, will result in more effective pathways towards sustainable development. Therefore, the research reported in this article answers the scholarly literature's call for greater investigation into corporate sustainability and its impact on sustainable community development in order to clearly define research direction and agenda. It also recommends ways to enact global goals at the corporate level. The article begins with a review of the literature on corporate sustainability and sustainable development at global and local levels. This is followed by sections on the methodology and data collection before discussing the final results. The manuscript finishes with a conclusion and recommendations for corporations in the mining industry in Zambia and elsewhere.

\subsection{Literature Review}

The demand for business sustainability dates as far back as the 18th century, even though the CSP concept only gained prominence during the 1960s $[1,10]$. Companies came up with ways in which they could give back to society as early as the mid-18th century [13]. The term 'society' in this context was somewhat limited to employee enhancement [14]. Companies normally ensured the comfortability of workers and their families through the provision of skills training, housing, and other amenities. However, after the implementation of neo-liberal economic policies in the 1980s and 1990s in developing countries that attracted massive investments from international corporations, power dynamics were affected within the local context in favor of the investors. Growing increasingly uncomfortable with the negative activities of multinational corporations, the media began to uncover and expose corporate scandals [15]. Suffice to say, these scandals changed the face of CSP. The relationship between business and society moved from just focusing mainly on employees to one that covered a range of diverse issues and became more global in scope [14]. The debate today by international organizations, academicians, and other interested parties isn't whether companies ought to do CSP or not but the extent to which it can contribute to sustainable development. This review provides an overview of CSP and linkages with sustainable development, particularly in the context of the mining industry. 


\subsection{Corporate Sustainability Performance: An Overview}

In recent decades, the concept of CSP has gradually acquired greater importance in academic and professional fields [1]. However, there has been little empirical research conducted on the impact of CSP in developing resource regions $[4,7,16]$ The main concern is that CSP in developing resource regions lacks collaboration with the government, the community, and the corporations towards the fostering of overall sustainability [7]. There has been a considerable amount of work on the notion of CSP mostly as a philanthropic approach to corporate performance, one which lacked the input of community members and the government $[2,17]$. Yet, CSP as an approach to sustainable development is an area that remains under-investigated [5]. Some scholars have found that CSP impact on sustainable development is negligible $[5,18,19]$ In the same vein, Lungu and Mulenga [20], while focusing on the Copperbelt, found that CSP was more concerned with profit-making than dealing with the concerns of various stakeholders, particularly those of communities. On the other hand, it has been found that CSP had a general significant positive impact on the local communities of the Niger Delta [21]. Focusing on education, Mayondi [22] found that the CSP of Barrick Gold, Zambia, had a slight positive impact. Still in Zambia, Kumar [23] found that CSP on various mining companies in the Copperbelt Province had a positive impact on education, health, and the environment. In the same vein, Whellams $[17,21]$ found that CSP had a positive impact in Ghana, Peru and Bolivia, respectively, in areas such as health, education, and livelihood. Despite the positive impact, Whellams [17] and Marias [19] are of the view that the extent to which CSP contributed to sustainable development is highly dependent on the design of the initiatives themselves and the composition of the local community.

\subsection{Sustainable Development in Mining}

Sustainable development (SD) is now a widely used notion to explain development issues [24]. The term became popularized after the 1987 Brundtland Commission's report titled "Our Common Future". In this report, sustainable development was defined as the "ability to make development sustainable - to ensure that it meets the needs of the present without compromising the ability of future generations to meet their own needs" [25]. This, however, can only be achieved through the integration and acknowledgement of economic, environmental, and social concerns throughout the decision-making process [26]. In the same vein, Dubiński [27] states that the implementation of SD means the integration of activities that ensure economic growth, natural resources, and environmental protection and, lastly, takes care of varying stakeholder needs.

The Sustainable Development Agenda, which was adopted by the United Nations (UN) in 2015, is a universal, integrated, and human rights-based program. It underscores connections between the environment, social justice, and development. Consequently, its associated 17 Sustainable Development Goals (SDGs) are wider and much more multidimensional in scope compared to the Millennium Development Goals (MDG), which was in vogue between 2000 and 2015 [28,29]. The MDG program was the first concerted effort at a global scale to address extreme poverty and basic health care needs. The eight identified goals were manageable, measurable, and, most importantly, could be easily identified by a wide range of stakeholders across the globe. During the 15-year period, the MDG program was able to achieve certain remarkable outcomes, although the progress was uneven. Therefore, there is a need to create a new framework to achieve inclusive sustainable development.

The SDGs encompass the millennium goals and, at the same time, incorporate several newer goals, such as building resilient infrastructure, promotion of inclusive and sustainable industrialization, and fostering innovation (SDG 9); reduction of inequality within and among countries (SDG 10); making cities and human settlements inclusive, safe, resilient, and sustainable (SDG 11); and ensuring sustainable consumption and production patterns (SDG 12), etc. The SDGs have become a framework to understand development, and therefore, this article focuses on how CSP in the mining industry can contribute to enacting the SDGs. In a nutshell, the SDGs are a set of 17 global goals consisting of an ambitious 169 targets and about 230 indicators [29]. The global goals represent the world's 
agreed comprehensive plan of action for equitable, socially inclusive, and environmentally sustainable economic development.

In the African context, achieving community development means integrating the SDGs into regional developmental plans such as the African Mining Vision, a continental policy for sustainable resource development and the African Agenda 2063 [30]. The latter seeks to address the many challenges associated with Africa's full maximization of mineral resources so as to enhance sustainable development. The African Mining Vision (AMV) further seeks to foster broad based sustainable growth and socio-economic development through transparency, and equitable and optimal exploitation of Africa's mineral resources. It is therefore a requirement for African Union (AU) member states, of which Zambia is a party, to adopt the AMV fully and also align it with national mineral sector policies as per the provisions of the framework. It is anticipated that through this action, Africa can fulfill the SDGs and other regional agendas [31].

\subsection{Corporate Sustainability Performance and Sustainable Development in Mining: A Local Perspective}

Since the beginning of large-scale mining in Zambia, social welfare policies that directly invest in human well-being have been deliberately implemented. For instance, back in the 1920s, the first mine under the private ownership of Roan Select Trust (RST) and Anglo-American Corporation (AAC) provided social amenities to employees [32]. The only problem with these policies was that they were racially biased, with Zambians being the least included for amenities [31]. After nationalization of the mines in the 1970s, the state became the key actor in shaping the economic and social agenda of the country through the creation of Zambia Consolidated Copper Mines (ZCCM) in 1982. The government was in charge of fostering sustainable development for the local people by providing social amenities such as free education for miners' children, subsidized housing and food, electricity, water, transport, raised employment, and also reoriented economic activities in various ways [33,34] This, however, did not last due to ZCCM's decline in copper production as a consequence of a combination of external market conditions, political instability affecting southern Africa at the time, and bad management decisions taken by ZCCM's executives and the Zambian government [35]. These issues led to the privatization programs of 1997 [36]. Despite the mines being in private hands, the practice of CSP in Zambia has continued.

Since the year 2000, Zambia has experienced increased copper production owing to massive investments in the mining industry [37]. Furthermore, the increased world base metal prices experienced in 2001 that were mainly influenced by demand for oil and metals by countries like China, Brazil, India, and a few other emerging markets played a significant role in increasing the copper output from Zambia at that time [38]. The argument is that the positive performance of the economy is directly related to increased investments in the mining sector [39]. Despite the many economic benefits of mining in Zambia, as well as the practice of CSP, poverty remains high in the country, specifically in mine host communities. Evidence shows that Zambia has $54.4 \%$ of its population living below the poverty line (K214.26 per Adult Equivalent), with $40.8 \%$ being extremely poor [40]. It is then helpful to understand the exact impacts of voluntary CSP on sustainable development and whether it in fact offers a long-term solution in addressing the poverty that is prominent in many poor but resource-rich countries.

\section{Materials and Methods}

Conducted in the Luanshya District of the Copperbelt Province, Zambia, this study was performed through the utilization of a mixed method, which involved the combination of a number of qualitative and quantitative methods and techniques, in order to reduce methodological limitations [41]. Specific techniques employed in this study include individual interviews of key informants such as local municipality council, ministry of mines, and the minerals development and public relations officer of CLM. Semi-structured questionnaires were administered to 200 Mpatamatu households, and open-ended questions were administered to a representative from the Ministry of Mines and Mineral 
Development and Luanshya Local Council. Purposive and snowballing sampling techniques were used to select respondents. Closed-ended questions were administered to the public relations officer of CLM. The study was also grounded on substantive literature and policy review. Furthermore, triangulation of available data was adopted to increase the reliability of the data collected [8].

\subsection{Case Study Location}

This study was conducted in the Luanshya District of the Copperbelt Province. The District is located $337 \mathrm{~km}$ from Lusaka and $35 \mathrm{~km}$ southwest of Ndola (Figure 1). Luanshya borders the Ndola District in the northeast, Kitwe District in the northwest, and Masaiti District in the southwest. The District covers a total of $935 \mathrm{~km}^{2}$, with $90 \%$ being urbanized and $10 \%$ rural [42]

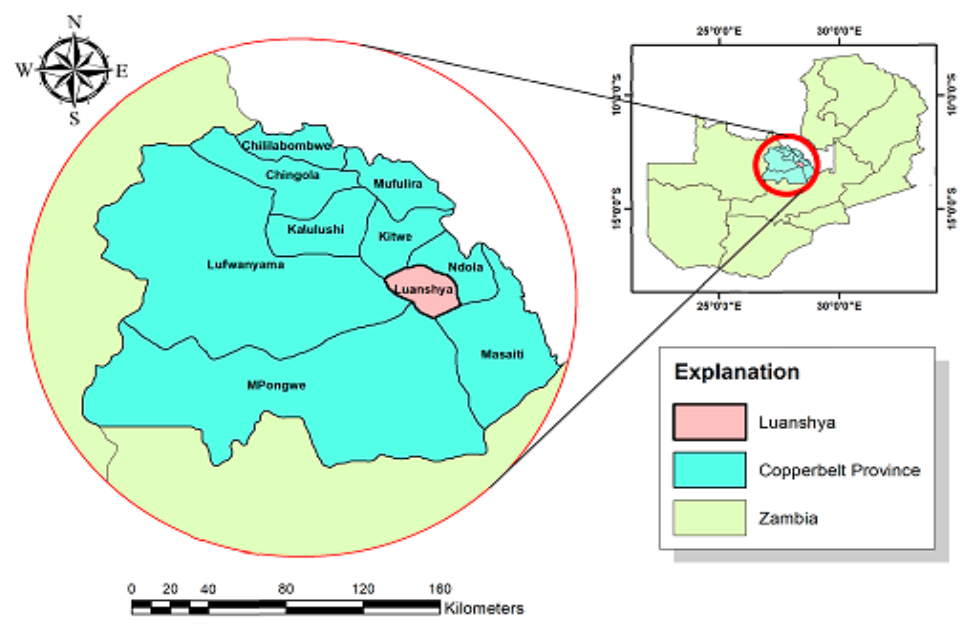

Figure 1. Map showing the location of Luanshya in the Copperbelt Province.

The study was based primarily on a single case study of the impact on CLM's CSP on local communities of the Mpatamatu compound in Luanshya, see Figure 2. The case for CLM is one that clearly demonstrates CSP in Zambia and may perhaps be representative of what goes on in other developing resource regions.

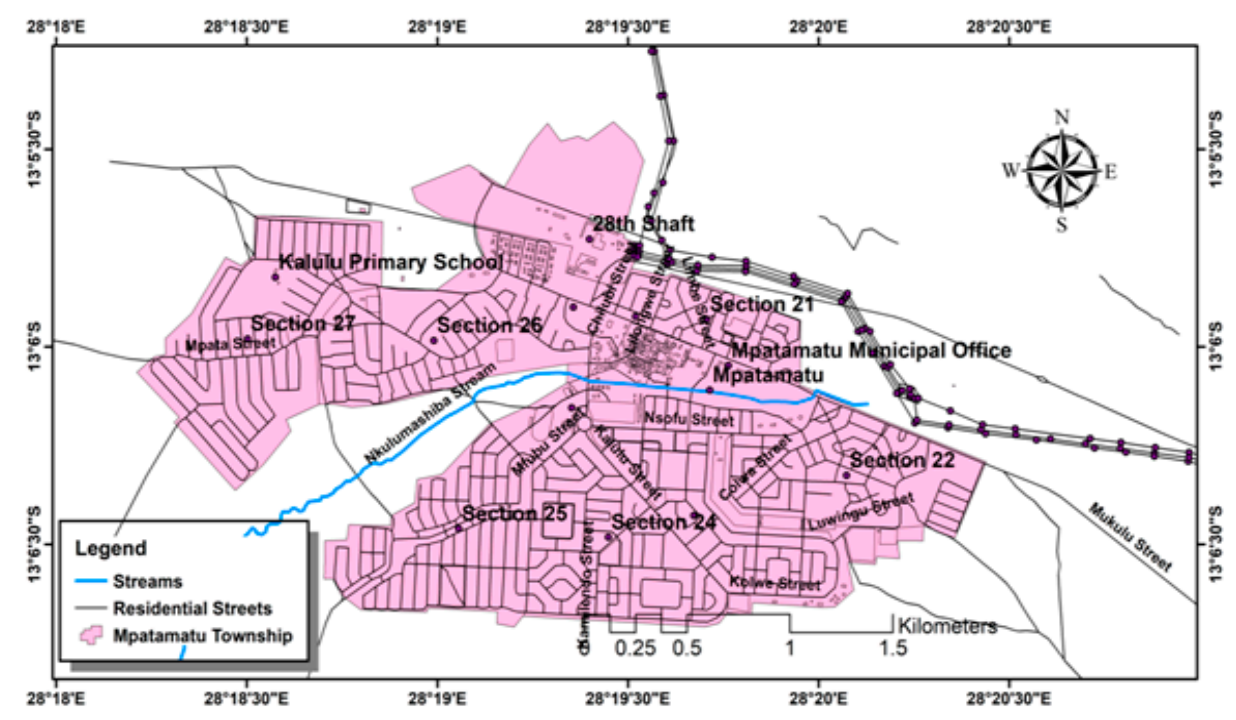

Figure 2. Map showing the Mpatamatu community. 


\subsection{Data Collection and Analysis}

The study adopted purposive sampling, which is a form of a non-probability sampling procedure; it is a technique used based on the knowledge, relationship, and expertise of sample members with regards to the research subject. Mpatamatu is the closest to the mine and comprises 4343 households in all seven sections (Sections 21 to 27). Stratified random sampling was used to select participants. The sample size was determined using the Slovin's formula $[43,44]$. To have a representative sample, 327 households were needed for sampling. The study only covered 200 households due to associated limitations proper to the scope of the project. The respondents were selected from three sections (Sections 21, 26, and 27) of Mpatamatu that were closest to the mine, representing 1784 households.

This study involved collecting and analyzing of both qualitative and quantitative forms of data in what is called the mixed method [11]. Using this method not only reduces or neutralizes the biases inherent in any single method but also serves as a transformative purpose for examining the current situation of vulnerable groups [11,12]. This method was therefore considered as best suited in dealing with issues of marginalized communities who are normally the intended beneficiaries of CSP initiatives in this case.

Data were collected from both primary and secondary sources. Primary sources of data employed the use of semi-structured interviews with selected key informants such as CLM public relations officers, a representative from the Ministry of Mines and Mineral Development, and Mpatamatu residents. Close-ended questions were used to collect information that could be quantifiable and comparable among participants [45]. On the other hand, open-ended questions were asked to understand and capture the points of view of people-without predetermining those points of view-through prior selection of questionnaire categories [46]. Responses from open-ended questionnaires provided insights about the local people's perceptions of CLM's CSP and how these have impacted their livelihoods. Secondary sources of data included company reports on CSP, official statistics from the Central Statistics Office (CSO), and other government organizations.

\section{Results}

This section discusses the findings derived from this research and is divided into two parts. The first part provides an outline of Luanshya mine's Corporate Sustainability Performance in alignment with the SDGs as applied to Mpatamatu. It then highlights the perception of CLM's CSP by Mpatamatu residents.

\subsection{Priority SDGs for Sustainable Community Development by CLM}

The Corporate Sustainability Performance for Luanshya Copper Mine is viewed as a way in which the company is able to respond to the interest of various stakeholders. The company invests in various CSP activities such as health, education, provision of employment through sports, infrastructure development, and agriculture as shown in Tables 1 and 2.

In terms of CSP investment between 2013 and 2016, the study established that CLM invested the most in health $(60 \%)$. CLM runs the Luanshya mine hospital and six other clinics. Some of the programs being run by the mine include the prevention of mother to child transmission, peer educators training, and the distribution of condoms. Furthermore, CLM has engaged in initiatives to combat epidemics such as Malaria and infectious diseases like Ebola and cholera. In order to enhance health and wellbeing, CLM ensures that the Mpatamatu community experiences little to no pollution through the use of cleaner technology. 
Table 1. Corporate Sustainability Performance (CSP) investment by the China Nonferrous Metals Group (CLM).

\begin{tabular}{|c|c|c|c|c|}
\hline Key SDGs & Category & Project Name & Beneficiaries of Project & Duration of Project \\
\hline SDG 4 & Education & $\begin{array}{l}\text { Trust and Luanshya } \\
\text { Craft School }\end{array}$ & Luanshya youths & Yearly \\
\hline \multirow{4}{*}{ SDG 3} & \multirow{4}{*}{ Health } & $\begin{array}{l}\text { Donations of sports } \\
\text { equipment Scholarships }\end{array}$ & School children & Yearly \\
\hline & & Luanshya hospital & $\begin{array}{c}\text { Miners and } \\
\text { Luanshya residents }\end{array}$ & Yearly \\
\hline & & Anti-malaria projects & $\begin{array}{l}\text { Miners and } \\
\text { Luanshya residents }\end{array}$ & 2014/done \\
\hline & & $\begin{array}{l}\text { Baby porridge for } \\
\text { vulnerable children }\end{array}$ & Vulnerable children & 2012/done \\
\hline \multirow[t]{2}{*}{ SDG9 } & \multirow{2}{*}{$\begin{array}{l}\text { Infrastructure } \\
\text { development }\end{array}$} & Construction of Gymnasium & The community & 2013/done \\
\hline & & $\begin{array}{l}\text { Construction of Zaone market } \\
\text { Rehabilitation Kafubu stadium }\end{array}$ & Luanshya residents & 2014/done \\
\hline \multirow[t]{3}{*}{ SDG 8} & \multirow[t]{3}{*}{ Employment Sports } & Salaries for Roan United Football Club & $\begin{array}{l}\text { Roan United } \\
\text { Football Club }\end{array}$ & Yearly \\
\hline & & $\begin{array}{l}\text { House rentals } \\
\text { win and draw bonuses }\end{array}$ & $\begin{array}{l}\text { Roan United } \\
\text { Football Club }\end{array}$ & Yearly \\
\hline & & Utility bills for Kafubu stadium & $\begin{array}{l}\text { Roan United } \\
\text { Football Club }\end{array}$ & Yearly \\
\hline SDG 2 & Donations (Agriculture) & Fertilizer and seed donations & $\begin{array}{c}\text { Selected } \\
\text { Luanshya farmers }\end{array}$ & Yearly \\
\hline
\end{tabular}

Table 2. CSP expenditure by CLM.

\begin{tabular}{cccccc}
\hline CSP Investment (ZMK) & $\mathbf{2 0 1 3}$ & $\mathbf{2 0 1 4}$ & $\mathbf{2 0 1 5}$ & $\mathbf{2 0 1 6}$ & Total per Sector \\
\hline Education & $4,155,682$ & $5,230,706$ & $5,026,738$ & $2,665,208$ & $17,078,335$ \\
Health & $11,738,190$ & $11,633,064$ & $10,704,354$ & $4,390,735$ & 0 \\
Infrastructure development & $1,205,000$ & 0 & 0 & $1,466,344$ \\
Employment-Sports & $1,797,323$ & $2,195,164$ & $1,756,328$ & 962,114 & 57,068 \\
Donations-Agriculture & 97,200 & 266,072 & 116,653 & $6,710,930$ \\
Yearly total & $18,993,395$ & $19,325,008$ & $17,604,074$ & $8,075,126$ \\
\hline
\end{tabular}


The study also revealed that $27 \%$ of CSP investment is directed towards education. CLM not only operates the Luanshya Craft Training School but also the Luanshya Trust School. While the former is a tertiary education institution, the latter offers primary and junior secondary education. Through the craft school community, members are able to gain various skills such as fitting, metal fabrication, and rigging. The school currently has a total of 110 trainees. The Trust school is also tailored majorly for employees' children and has an enrolment of 630 pupils. In addition to the above, the company provides a bursary scheme for school leavers. Every year, the company awards scholarships to 10 selected candidates to study mining engineering, metallurgy, and engineering at the local universities, i.e., University of Zambia and the Copperbelt University.

In relation to employment, the study established that $10 \%$ of CSP investment was directed towards the Roan United Football Club. The company was in charge of not only monthly wages for the club but also other logistics during away matches. Infrastructure development constitutes $2 \%$ of the community. CLM constructed Zaone market, improved the road network that leads to the mine, refurbished play parks, as well as constructed a modern gym and a swimming pool for the youths. The research revealed that through random donations, CLM invests $1 \%$ to supporting selected small-scale farmers in Luanshya with agriculture support inputs such as fertilizer and seed. In order to effectively select the vulnerable but viable farmers to assist with agriculture input, the mine has deliberately taken a step to partner with the government through the district agriculture coordinating officer and the area members of parliament.

In terms of CSP investment between 2013 and 2016, the study established that CLM invested the most in health $(60 \%)$. Education made up $27 \%$ of investments, while $10 \%$ was directed towards employment through sport and $2 \%$ to infrastructure development. Agriculture was the least invested in, with $1 \%$ of CSP investment (see Figure 3).

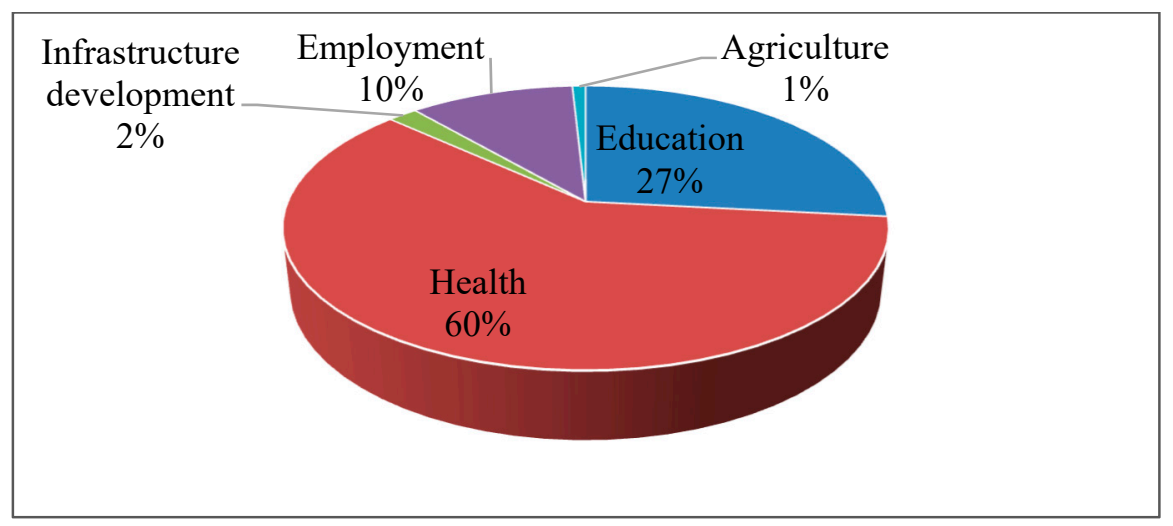

Figure 3. Keys areas of CSP at the company level.

\subsection{Key SDGs for Sustainable Community Development by the Community}

However, at the community level, the study found that $32 \%$ of respondents considered agriculture as the most important CSP investment, followed by employment at $26 \%$, then education at $23 \%$. On the other hand, health made up $10 \%$ and infrastructure development was at $9 \%$, and these were least preferred, as shown in Figure 4. 


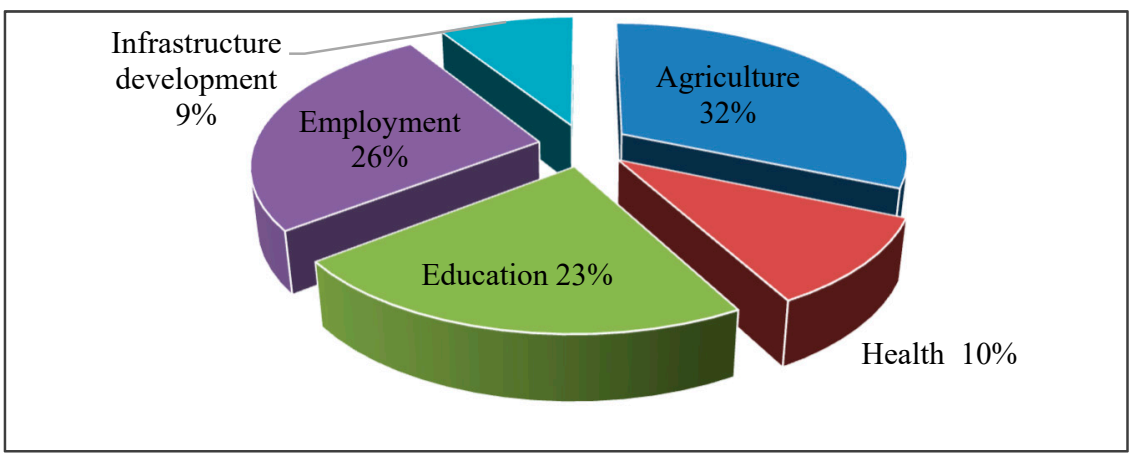

Figure 4. Key CSP areas based on perception of Mpatamatu residents.

\subsection{CLM's CSP Contribution to Achieving SDGs}

\subsubsection{Impact on Agriculture (SDG 2)}

The study revealed that out of 78 farmers, $87 \%$ were small scale farmers and the rest were commercial farmers. Of all the farmers, $89 \%$ had no land of their own, with $77 \%$ small scale and $12 \%$ commercial farmers on mine property. Of the small-scale farmers, 3\% were on customary land and $7 \%$ on private property. The study established that only $1 \%$ were practicing commercial farming on their own property, as shown in Figure 5.

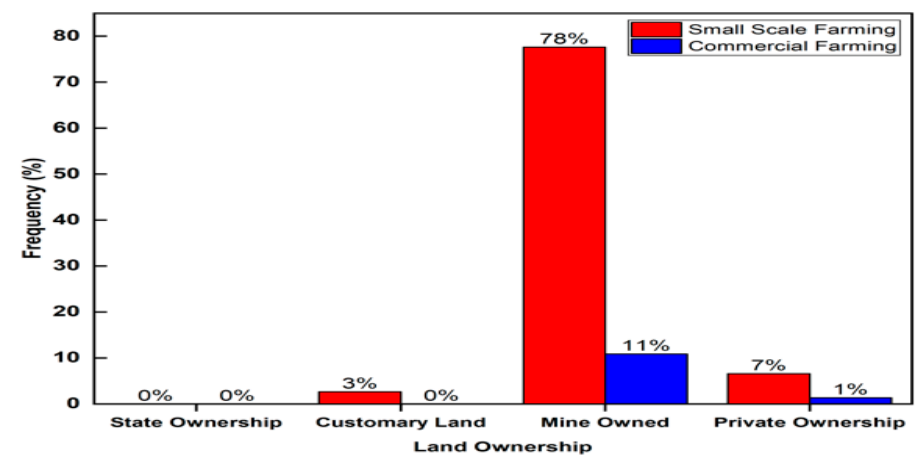

Figure 5. Type of farming and land ownership.

The study therefore established a weak positive correlation between income and land ownership for the people of Mpatamatu, as shown in Table 3. This result implies that the income of households increased with an increase in land ownership, whereas a household earning power increased with owning productive land.

Table 3. Correlation between monthly household income and land ownership.

\begin{tabular}{cccc}
\hline & & 1 & 2 \\
\hline 1 & Monthly household & income \\
2 & Land ownership & - & - \\
\hline \multicolumn{4}{c}{ Note. $\mathrm{N}=76 .{ }^{*} p<0.05}$.
\end{tabular}

Furthermore, over $70 \%$ of the households denied knowing any kind of support that CLM renders to farmers. The remaining 30\% were split between those who agreed and those who could neither agree nor disagree (Figure 6). 


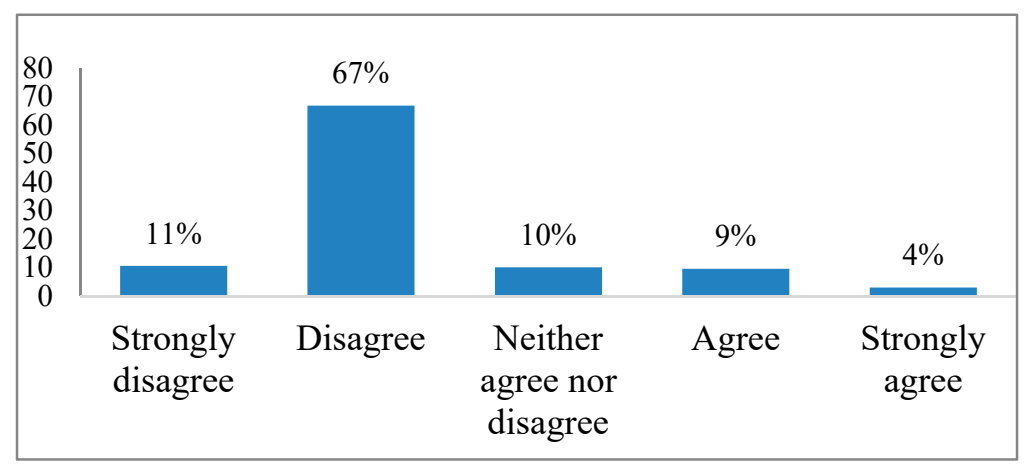

Figure 6. Agricultural support to enhance productivity.

\subsubsection{Impact on Health (SDG 3)}

With regards to the provision of health facilities and services, the study revealed that $70 \%$ of the respondents indicated that they not only attended the mine health facility when ill, they also agreed to the provision of such services by CLM. On the other hand, the remaining $30 \%$ who went to the Government health facility also denied or could not confirm the provision of healthcare services by CLM (Figure 7).

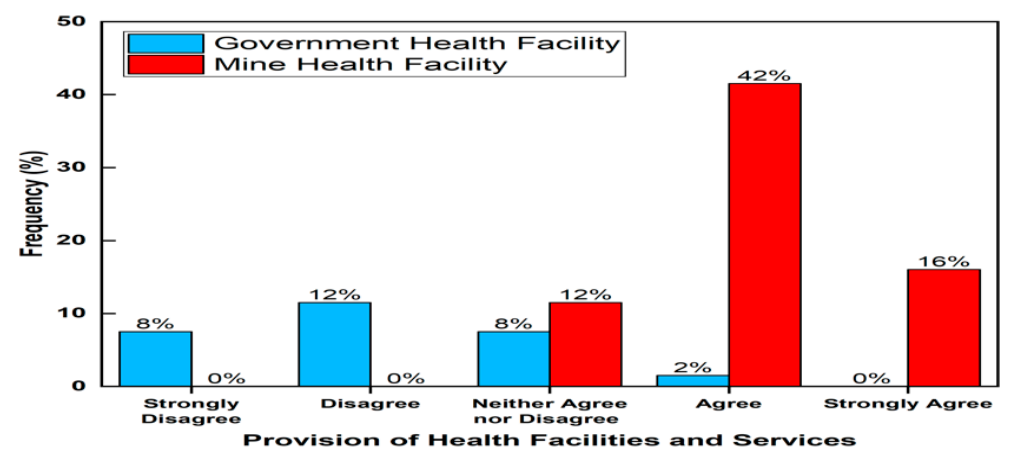

Figure 7. Provision of healthcare services and facilities.

The study further established that $90 \%$ of the locals did not experience any mine pollution of any sort. The remaining $10 \%$ that experienced pollution were found a stone's throw away from the Muliashi open pit mine project, see Figure 8.

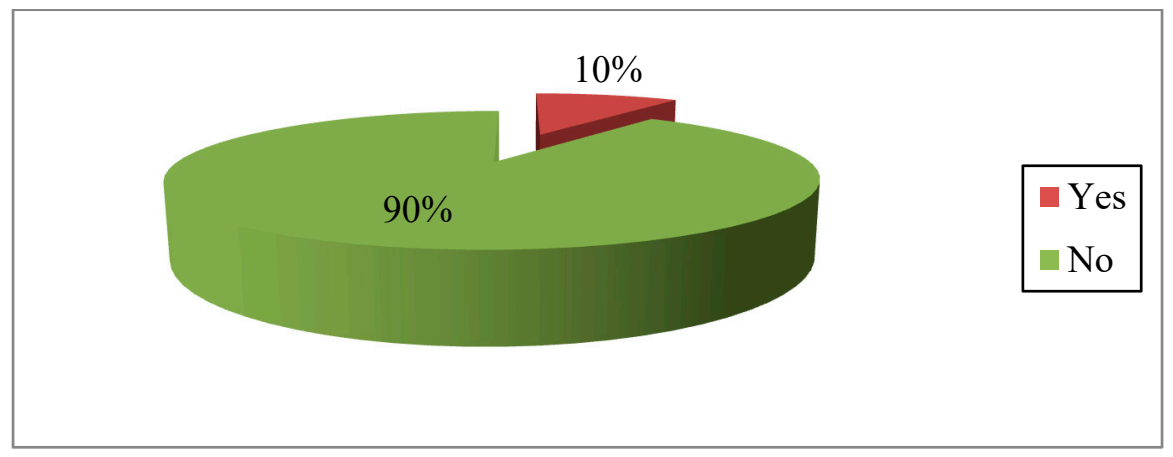

Figure 8. Pollution experienced by Mpatamatu residents.

\subsubsection{Impact on Education (SDG 4)}

The findings revealed that only $2 \%$ of the participants had obtained their tertiary level qualification from the Luanshya Craft School and none from the Trust School. The respondents who had senior secondary qualifications were represented by $33 \%$ and tertiary level qualifications by $11 \%$. The rest of 
the population had junior level qualifications and below. The study found that the government was the major provider of education in the community, with over $90 \%$ of the participants having attended government schools during their last level of education (Figure 9).

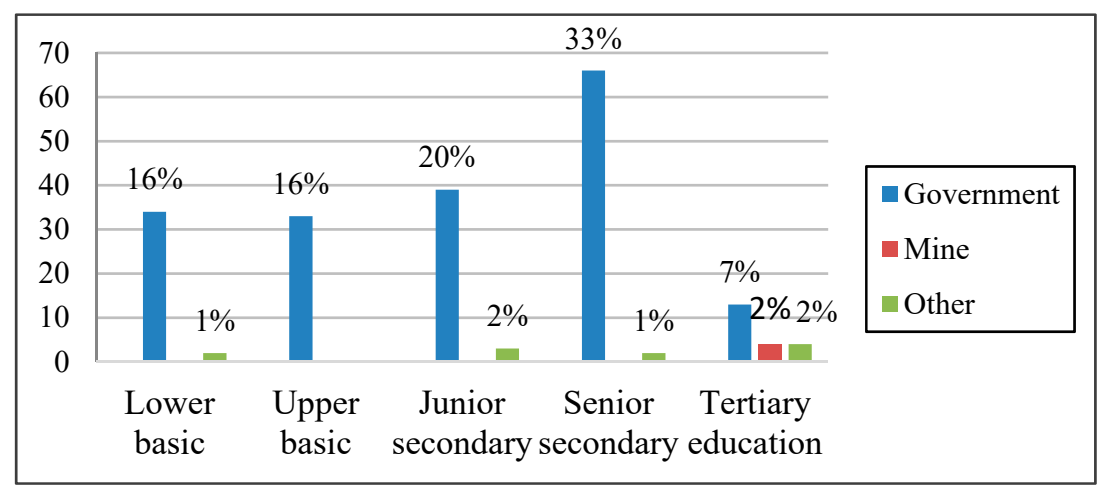

Figure 9. Level of education and school attended.

The study established that the majority of the population, $54 \%$ and $82 \%$, disagreed with the fact that CLM provides schools and scholarships, respectively. Furthermore, it was established that only $25 \%$ and $6 \%$ of the population confirmed the provision of schools and scholarships, respectively, as shown in Figure 10.

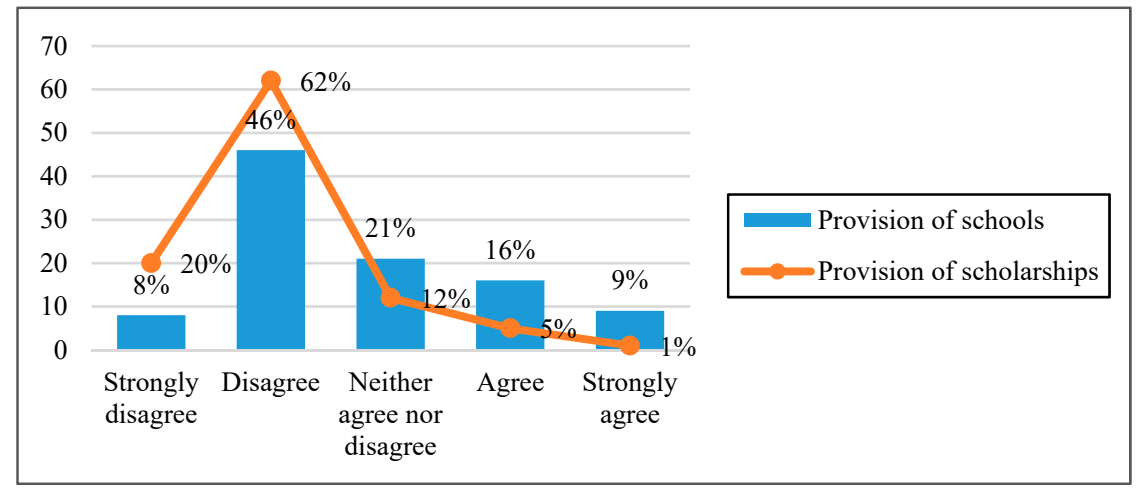

Figure 10. Provision of schools and scholarships.

Furthermore, the study found that respondents who were more educated also earned more as they were able to get into formal employment. The results also revealed that most locals attended schools offered by CLM at the tertiary level because the Craft school was tailored more for community members while the Trust school was mostly for miners' children (Table 4).

Table 4. Correlation of variables relating to education.

\begin{tabular}{ccccccc}
\hline \multicolumn{1}{c}{} & $\mathbf{1}$ & $\mathbf{2}$ & $\mathbf{3}$ & $\mathbf{4}$ & $\mathbf{5}$ \\
\hline 1 & Education & & & & & \\
2 & Provision of schools & $0.23^{* *}$ & & & & \\
3 & Income & $0.27^{* *}$ & $0.18^{*}$ & & & \\
4 & Scholarships & $0.16^{*}$ & $0.14^{*}$ & -0.02 & & \\
5 & School attended & $0.33^{* *}$ & $0.27^{* *}$ & 0.09 & $0.39^{* *}$ & \\
\hline
\end{tabular}




\subsubsection{Employment (SDG 8)}

In relation to employment (Figure 11), the study found that $39 \%$ of households were farmers who grew crops and vegetables to sustain their families. Those trading in small merchandise represented $24 \%$. CLM employees represented $20 \%$ while $8 \%$ were civil servants. Those unemployed made up 9\% of the participants.

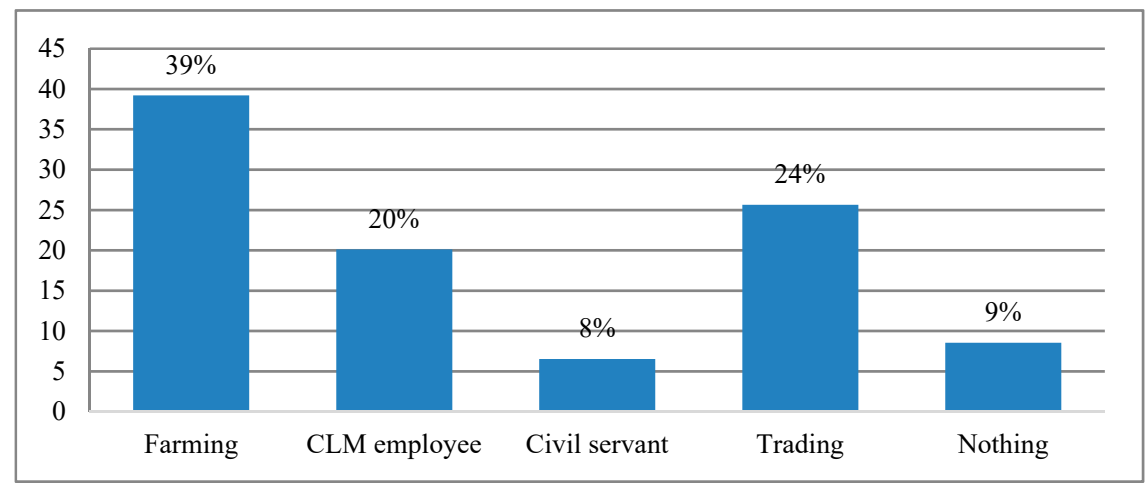

Figure 11. Sources of income for Mpatamatu residents.

The results show that out of 39 mine workers, the majority earned between K501 and K1000 while the rest earned above K1000. The study also revealed that what people did for a living was not sufficient to meet monthly household expenses despite them being in formal or informal employment (see Tables 5 and 6).

Table 5. Cross tabulation of sources of income and monthly household income.

\begin{tabular}{ccccccc}
\hline & Below K100 & K100-K500 & K501-K1000 & K1001-K3000 & K3001-K5000 & K5001 and above \\
\hline Farming & 0 & 23 & 34 & 18 & 2 & 0 \\
CLM & 0 & 0 & 31 & 6 & 1 & 1 \\
employee & 0 & 0 & 3 & 6 & 2 & 1 \\
Civil servant & 5 & 22 & 18 & 4 & 0 & 0 \\
Trading & 11 & 3 & 1 & 1 & 0 & 0 \\
Nothing & 1 & & & & & \\
\hline
\end{tabular}

Table 6. Correlations of variables relating to employment.

\begin{tabular}{cccccc}
\hline & & $\mathbf{1}$ & $\mathbf{2}$ & $\mathbf{3}$ \\
\hline 1 & Income sources & & & \\
2 & Monthly income & $-0.34^{* *}$ & & \\
3 & Monthly expenses & $-0.23^{* *}$ & $0.45^{* *}$ & \\
4 & People per & $-0.19^{* *}$ & $0.24^{* *}$ & $0.14^{*}$ \\
\hline
\end{tabular}

Note. $\mathrm{N}=200 .{ }^{*} p<0.05 ;{ }^{* *} p<0.01$.

\subsubsection{Infrastructure Development (SDG9)}

The study revealed that $37 \%$ denied knowing any efforts directed towards infrastructure while $16 \%$ could not confirm, and 47\% knew about CLM's efforts towards advancing infrastructure development. The results are shown in Figure 12. 


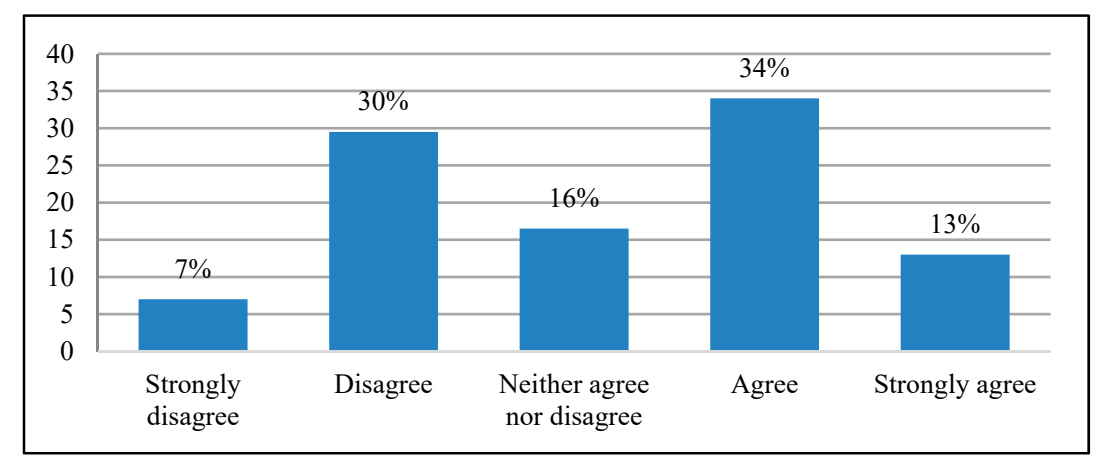

Figure 12. Availability of infrastructure.

\section{Discussion}

The research found that there was a mismatch in CSP priorities of CLM and local communities. While CLM focused on health, education, employment, infrastructure development, and agriculture, the locals, on the other hand, considered agriculture as very important, followed by employment and educational support as moderately important, and health and infrastructure development as least important. This difference indicates that CSP programs are often done in the absence of various stakeholders. Cheelo [22] established that CSP had a horizontal kind of communication where there was no trickle down of information from shareholders to stakeholders [37]. To avoid excluding stakeholders in decision-making processes, the literature suggests using a triangular kind of communication that allows corporations to be inclusive of all stakeholders $[47,48]$.

\subsection{Impact on Agriculture (SDG 2)}

According to the Geneva International Centre for Humanitarian Demining (GICHD) and the United Nations Development Program (UNDP), the contributions of mining towards the achievement of SDG 2 are through freeing up access to economic markets and natural resources [49]. In this way, mining firms can provide livelihood opportunities and yield productivity improvements to affected communities, thus helping to address poverty, malnutrition, and food security. This study found that the majority of the households were farmers of which $89 \%$ had no land of their own. Jayne et al. [50] argue that there exists a relationship between land access and household income. In the same vein, Muraoka et al. [51] established that constrained access to land impedes long term land investments and productivity, thus affecting national food security and poverty reduction in Africa.

Agricultural support in this case could be the promotion of modern techniques of production including the application of fertilizers, the use of hybrid seeds, and the provision of credit facilities, among other things [52]. Over 70\% of the households denied knowing any kind of agricultural support CLM renders to farmers. The findings show that CLM is not actively supporting the smallholder farmers in a way that increases food productivity and food security as is the aspiration of SDG 2. These findings differ from those found by Whellams [17], who established that CSP had a positive impact on the farming community of Yanachocha in terms of the increase in crop yields, promotion of linkages among producers, improvement of agricultural labor quality, and technology transfer.

\subsection{Impact on Health (SDG 3)}

Mines can contribute to SDG 3 by providing safe access to healthcare facilities and services as in the case of CLM [49]. In terms of pollution, the study found that $90 \%$ of the households did not experience any pollution at all. However, the $10 \%$ that experienced air pollution were households located a stone-throw away from the new Muliashi open pit mine project. In this regard, CLM actively curbs the impact of the dust produced at the mine project by constantly suppressing the dust using the water spraying technique [53]. The findings show that CLM had a significant positive impact on the provision of healthcare services and facilities and pollution control. These results are consistent with 
the findings of Whellams [17,23,54], and contradict those found by Mensah [18], who found no impact on health in Ashanti, Ghana.

\subsection{Impact on Education (SDG 4)}

The need for quality education and lifelong learning opportunities for a full productive life to all individuals and the realization of sustainable development cannot be over emphasized [53]. As such, mining companies must help the communities they found themselves in to acquire literacy and numeracy. The provision of such services must be inclusive and equitable to all boys and girls, and women and men alike. Despite the fact that CLM runs the two schools, the field findings revealed that only $2 \%$ of the participants had obtained their tertiary level qualification from the Luanshya Craft School and none from the Trust School. The participants that had secondary and tertiary level qualification were $33 \%$ and $14 \%$, respectively. The rest of the population had junior level qualifications and below. The study found that the government was the major provider of education in the community, with over $90 \%$ of the participants having attended government schools during their last level of education. The fact that preference for awarding these bursaries was given to miners' children explained why $82 \%$ of the research participants were ignorant about the existence of the scholarships. The findings in this study resonate with those of Mayondi $[22,23,54]$, who also found a slight positive impact of CSP on education.

\subsection{Impact on Employment (SDG 8)}

The findings of the study are similar to those shown by Lungu and Mulenga [20], who found that miners in Luanshya were being paid K400. These findings also resonate with Madeley [55], who notes that most of the jobs provided by multinational corporations tend to be low-skilled, low-paid, and geared to a particular company operation. Workers therefore perform small, specialized tasks of a large operation. Such tasks, as the author puts it, are likely to turn workers into little more than the arm of a machine and not necessarily equip them with skills they can use elsewhere in domestic enterprises, for example. The creation of jobs and other such opportunities for the local people would guarantee monthly household income, hence offering stability of livelihoods. However, the findings of this study do not explicitly indicate a positive impact on income and livelihood. Whellams [17], on the other hand, established that an increase in income in Yanacocha was not because of direct employment of the locals at the mine but because of skill transfer and entrepreneurial opportunities that increased economic productivity. In a similar study done by Marais [19], it was discovered that through running of different enterprise development and empowerment initiatives, Anglo American was able to create sustainable and commercially viable businesses for the people of South Africa. Abe and Franco [56] note that achieving higher levels of economic productivity requires more than diversification, an upgrade in technology, and innovation that places emphasis on high added value and labor intensive sectors. In the same vein, it is believed that sustained and inclusive economic growth drives development through the provision of more resources for education, health, personal consumption, transport, water, and energy infrastructure [53]. This way, economic growth can lead to new and better employment opportunities. It therefore cannot be said that CSP has had a positive impact on SDG 8.

\subsection{Impact on Infrastructure Development (SDG 9)}

CLM has so far constructed the Zaone market, improved the roads, as well as constructed a modern gym and refurbished play parks in the area. The findings in the field revealed that $47 \%$ agreed to having the aforementioned infrastructure. Evidence shows that investing in infrastructure, promoting inclusive and sustainable industrialization, as well as supporting technological development, research, and innovation are three driving forces for economic growth and sustainable development [53]. It is believed that these drivers can help countries reduce poverty by not only creating job opportunities and stimulating growth but also encouraging the building and improvement of physical facilities that are essential to the functioning of business and society. With regards to the infrastructure in Mpatamatu, 
it can be concluded that the investments in infrastructure are not enough to impact on sustainable community development.

\section{Conclusions}

The study found that there was a mismatch between the priorities of the company and that of local communities. The study further found that the residents of Mpatamatu experienced a general positive impact in health (SDG 3) in regard to the provision of health facilities and environmental management. In terms of agriculture (SDG 2), the residents do not own land of their own as most of them farm on mine property. It was established that CSP had no impact on agriculture as CLM did not provide any farming inputs, skills training, or any financial assistance to farmers. This has limited the productivity of the local community as farming is done mainly on small scale. The study further revealed that there was negligible impact on education (SDG 4) as CLM provides schooling opportunities for miners' children and those who can afford it. In relation to employment (SDG 8), the study found little impact on employment as the company provides low-skilled jobs. These jobs were, however, not sufficient to meet the needs of most of the residents. In terms of infrastructure (SDG 9), no new buildings have been put up since building a market, stadium, gym, and pool in 2013. CSP, therefore, had no meaningful impact on infrastructure development as the type of buildings the company had invested in were not able to bring industrialization or broader sustainable community development.

The study found that CSP programs of CLM were mostly philanthropic in nature and lacked a guiding framework. The above results confirm that CSP has been used as a green wash strategy by mining firms due to the fact that more effort is placed on charitable short-lived micro-level activities rather than addressing larger failures of corporate accountability and weak governance. In as much as it is argued by Carroll [14] and other proponents of the stakeholder theory that business does indeed have the resources to solve society's problems, the findings of the study support the view point of Mertens [12], who states that it is impossible for businessmen to determine what constitutes society's interest.

The impact that CSP could possibly have on sustainable community development is one that has not been fully investigated in relation to developing resource regions, with an exception of countries like South Africa, Ghana, Nigeria, and a few others. This scarcity of knowledge has created a knowledge gap on the extent to which CSP should be pushed as a panacea in fostering development in resource-rich developing countries. The advancement of CSP as a development agenda is one that neglects the fact that the CSP concept is of western origin and, as such, might not exactly be tailored for developing countries that have different political, historical, and cultural backgrounds. It is for these reasons that this research sought to fill this knowledge gap by examining whether CSP does indeed have potential to change the fate of poverty-stricken resource-rich countries like Zambia.

Author Contributions: I.M. engaged in data collection, analysis and development of the manuscript. I.B.F. made major contributions to the developed of the research design, methodology and development of the manuscript. M.J. provided overall supervision, funding and project administration.

Funding: This research received no external funding.

Conflicts of Interest: The authors declare no conflict of interest.

\section{References}

1. Carroll, A.B.; Shabana, K.M. The Business Case for Corporate Social Responsibility: A Review of Concepts, Research and Practice. Int. J. Manag. Rev. 2010, 12, 85-105. [CrossRef]

2. Jamali, D.; Mirshak, R.J. Corporate Social Responsibility (CSR): Theory and Practice in a Developing Country Context. J. Bus. Ethics 2007, 72, 243-262. [CrossRef]

3. Eweje, G. The Role of MNEs in Community Development Initiatives in Developing Countries: Corporate Social Responsibility at Work in Nigeria and South Africa. Bus. Soc. 2006, 45, 93-129. [CrossRef] 
4. Idemudia, U. Corporate Social Responsibility and Developing Countries: Moving the Critical Agenda in Africa Forward. Prog. Dev. Stud. 2011, 11, 1-18. [CrossRef]

5. Franco, I.; Ali, S. Decentralization, Corporate Community Development and Resource Governance: A Comparative Analysis of Two Mining Regions in Colombia. Extr. Ind. Soc. 2016, 4, 111-119. [CrossRef]

6. Blowfield, M.; Frynas, J.G. Setting new agendas: Critical perspectives on corporate social responsibility in the developing world. Int. Aff. 2005, 3, 499-513. [CrossRef]

7. Prieto-Carrón, M.; Lund-Thomsen, P.; Chan, A.; Muro, A.; Bhushan, C. Critical perspectives on CSR and development: What we know, what we don't know, and what we need to know. Int. Aff. 2006, 82, 977-987. [CrossRef]

8. Yin, R. Case Study Research Design and Methods; Sage Publications: London, UK, 2009.

9. Striking, A. Better Balance: The World Bank Group and Extractive Industries: The Final Report of the Extractive Industries Review; World Bank: Washington, DC, USA, 2004.

10. Broomhill, R. Corporate Social Responsibility: Key Issues and Debates Dunstan Pap. 1; The Don Dunstan Foundation: Adelaide, SA, Australia, 2007.

11. Creswell, J.W. Research Design. Qualitative, Quantitative and Mixed Methods Approaches; Sage Publication: Thousand Oaks, CA, USA, 2003.

12. Mertens, E.M.K. Milton Friedman and Social Responsibility: An Ethical Defense of the Stockholder Theory; The University of Oslo: Oslo, Norway, 2013.

13. Katsoulakos, P.; Koutsodimou, M.; Matraga, A.; Williams, L. A Historic Perspective of the CSR Movement. CSR Quest Sustainability Framework 2004, 5, 28.

14. Carroll, A.B. A History of Corporate Social Responsibility: Concepts and Practices. In Oxford Handbooks of Corporate Social Responsibility; Oxford University Press: Oxford, UK, 2015; pp. 1-20.

15. Jenkins, R. Globalization, Corporate Social Responsibility and Poverty. Int. Aff. 2005, 81, 525-540. [CrossRef]

16. Kolk, A.; Tulder, V.R. International business, corporate social responsibility and sustainable development. Int. Bus. Rev. 2010, 19, 119-125. [CrossRef]

17. Whellams, M. The Role of CSR in Development: A Case Study Involving the Mining Industry in South America; Saint Mary's University: Halifax, Canada, 2007.

18. Mensah, V. The Role of Corporate Social Responsibility on Sustainable Development: A Case Study of the Mining Community in the Obuasi Municipality. Master's Thesis, University of Agder, Kristiansand, Norway, 2009.

19. Marias, A. Assessing Corporate Social Responsibility in Terms of its Impact on Sustainable Community Development: Anglo American Plc Programmes as Case Study. Ph.D. Thesis, University of Stellenbosch, Stellenbosch, South Africa, 2010.

20. Lungu, J.; Mulenga, C. Corporate Social Responsibility Practices in the Extractive Industry in Zambia. ResearchGate 2005. [CrossRef]

21. Amadi, O.B.; Abbudullah, H. Poverty Alleviation through Corporate Social Responsibility in Niger Delta, Nigeria. Asian Soc. Sci. 2012, 8, 57. [CrossRef]

22. Mayondi, W. Mining and Corporate Social Responsibility in Zambia: A Case Study of Barrick Gold Mine; Victoria University of Wellington: Wellington, New Zealand, 2014.

23. Kumar, R. Corporate Social Responsibility in Copperbelt of Zambia. Int. J. Sci. Technol. Manag. 2016, 5, 142-149.

24. Hopwood, B.; Mellor, M.; Brien, G.O. Sustainable Development: Mapping Different Approaches. Sustain. Dev. 2005, 13, 38-52. [CrossRef]

25. Mining Minerals and Sustainable Development Project. Breaking New Ground; Earthscan Publications Ltd.: London, UK, 2002.

26. Emas, R. Brief for GSDR 2015 The Concept of Sustainable Development: Definition and Defining Principles; Florida International University: Miami, FL, USA, 2015.

27. Dubiński, J. Sustainable Development of Mining Mineral Resources. J. Sustain. Min. 2013, 12, 1-6. [CrossRef]

28. UNDP. The Millennium Development Goals Report; UNDP: New York, NY, USA, 2015.

29. Barbier, B.E.; Burgess, C.J. The Sustainable Development Goals and the Systems Approach to Sustainability. Econ. Discuss. Pap. 2017, 28, 2.

30. Oxfam. From Aspiration to Reality: Unpacking the Africa Mining Vision. Briefing Paper; Oxfam: Nairobi, Kenya, 2017. 
31. Weeks, J.; Chisala, V.; Geda, A.; Dagdeviren, H.; McKinley, T.; Saad Filho, A.; Oya, C. Economic Policies for Growth, Employment and Poverty Reduction: Case Study of Zambia; United Nations Development Programme: New York, NY, USA, 2006.

32. Fraser, A.; Lungu, J. For Whom the Windfalls? Winners and Losers in the Privatization of Zambia's Copper Mines; Springer: Berlin/Heidelberg, Germany, 2007.

33. Lindahl, J. Environmental impact of mining in Zambia: Towards Better Environmental Management and Sustainable Exploitation of Mineral Resources. SGU-rapport. Geol. Surv. Swed. 2014, 27, 27.

34. Simpasa, M.A.; Meller, P.; Lara, B.; Valdés, G. Role of Copper in the Chilean E Zambian Economies: Main Economic and Policy Issues; GDN: New Delhi, India, 2013.

35. Léniz, F.C. Histories of Nationalization and Privatization: The Cases of the Chilean and Zambian Copper Industries; Fundación Chile: Santiago, Chile, 2001.

36. China Nonferrous Mining Corporation Limited (C.L.M). 2014 Annual Report; Deutsche Post: Bonn, Germany, 2014.

37. Cheelo, K.H. 2008 Behind the Economic Figures: Large-scale Mining and Rural Poverty Reduction in Zambia: the Case of Kansanshi Copper Mine in Solwezi: A Thesis Presented in Partial Fulfillment of the Requirements for the Degree of Master of Philosophy in Development Studies.

38. Adam, C.; Simpasa, A.M. The Economics of the Copper Price Boom in Zambia; Springer: New York, NY, USA, 2010.

39. Ministry of Finance and National Planning. Economic Report 2006; Ministry of Finance and National Planning: Lusaka, Zambia, 2007.

40. Central Statistics Office (CSO). Living Conditions Monitoring Survey Report; CSO: Cork, Ireland, 2015.

41. Singleton, R.J.; Straits, C.B. Approaches to Social Research; Oxford University Press: New York, NY, USA, 2010.

42. Luanshya District and Housing Office. Preliminary Report; Census: Luanshya, Zambia, 2011.

43. Almeda, J.; Capistrano, T.; Sarte, G. Elementary Statistics; Up press: Quezon City, Philippines, 2010.

44. Tejada, J.J.; Punzalan, J.R.B. On the Misuse of Slovin's formula. Philipp. Stat. 2012, 61, 129-136.

45. Will, A.S. Community-Based Urban Solid Waste Management: A Case Study of SUVA, Fiji; Massey University: Palmerston North, New Zealand, 2007.

46. Patton, M.Q. Qualitative Research and Evaluation Methods; Sage Publication: Thousand Oaks, CA, USA, 2002.

47. Franco, I. Building Sustainable Communities: Enhancing Human Capital in Resource Regions; The University of Queensland: Brisbane, Australia, 2014.

48. Masinja, H.J. The Use of Corporate Social Responsibility as a Means of Engaging the Host Communities. A Case Study of the Zambian Mining Industry; Stellenbosch University: Stellenbosch, South Africa, 2016.

49. UNDP, GICHD. Leaving No One Behind: Mine Action and the Sustainable Development Goals; UNDP: New York, NY, USA; GICHD: Geneva, Switzerland, 2017.

50. Jayne, T.S.; Yamano, T.; Weber, M.T.; Tschirley, D.; Benfica, R.; Chapoto, A.; Zulu, B. Smallholder income and land distribution in Africa: Implications for poverty reduction strategies. Food Policy 2003, 28, 253-275. [CrossRef]

51. Muraoka, R.; Jin, S.; Jayne, T.S. Land access, land rental and food security: Evidence from Kenya. Land Policy 2018, 70, 611-622. [CrossRef]

52. Chirwa, W.E. Access to Land, Growth and Poverty Reduction in Malawi; University of Malawi: Zomba, Malawi, 2004.

53. United Nations. The Sustainable Development Goals Report 2017; UNSD: New York, NY, USA, 2017.

54. Boon, K.E.; Ababio, F. 2009 Corporate Social Responsibility in Ghana: Lessons from the mining sector. In Proceedings of the 29th Annual Conference of the International Association for Impact Assessment, Accra, Ghana, 7-22 May 2009; pp. 16-29.

55. Madeley, J. Big Business, Poor Peoples: The Impact of Transnational Corporations on the World's Poor; Zed books: London, UK, 2003.

56. Abe, M.; Franco, B.I. A Model for a Model for Future Sustainable for Future a Model Sustainable; United Nations Publication: New York, NY, USA, 2017.

(C) 2019 by the authors. Licensee MDPI, Basel, Switzerland. This article is an open access article distributed under the terms and conditions of the Creative Commons Attribution (CC BY) license (http://creativecommons.org/licenses/by/4.0/). 